Click www.researchjournal.co.in/online/subdetail.html to purchase.

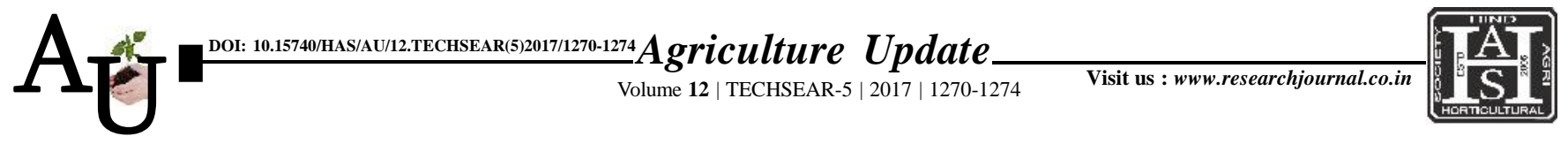

\title{
Research article: Comparative studies on the effect of different sources of sulphur in relation with forms of sulphur and soil properties in calcareous soil
}

\author{
K.K. AMRUTHA, M.V. RAVI, K. NARAYANA RAO, H.S. LATHA AND SOUMYA \\ KULKARNI
}

Article Chronicle:

SUMMARY : The effect of sulphur application on soil sulphur forms and physico-chemical properties was investigated in calcareous black soil under field capacity condition at soil science and agricultural chemistry laboratory in UAS Raichur in 2016. Among the different sources of sulphur ammonium 15.07.2017:

Accepted :

30.07.2017

KeY Words: sulphate was shown high effectiveness and followed by gypsum, elemental sulphur and pyrite. Sulphur fertilization improved the sulphur forms and physico-chemical properties in the calcareous soil.

How to cite this article : Amrutha, K.K., Ravi, M.V., Rao, K. Narayana, Latha, H.S. and Kulkarni, Soumya (2017). Comparative studies on the effect of different sources of sulphur in relation with forms of sulphur and soil properties in calcareous soil. Agric. Update, 12(TECHSEAR-5) : 1270-1274; DOI: 10.15740/HAS/AU/ 12.TECHSEAR(5)2017/1270-1274.

Calcareous soil, Sulphur fertilizers, Forms of sulphur, Physico-chemical properties

Author for correspondence :

\section{K.K. AMRUTHA}

Department of Soil Science and Agricultural Chemistry, College of Agriculture, University of Agricultural Sciences, RAICHUR (KARNATAKA) INDIA

See end of the article for authors' affiliations 